\title{
タイ拠点大学交流事業「薬学分野：天然薬物」
}

済木育夫, ${ }^{*, a}$ 山崎美佳子, ${ }^{b}$ 松 本 欣三 ${ }^{c}$

\section{JSPS-NRCT Core University Program on Natural Medicine in Pharmaceutical Sciences}

\author{
Ikuo SAIKI, ${ }^{*, a}$ Mikako YAMAZAKI, ${ }^{b}$ and Kinzo MATSUMOTO ${ }^{c}$ \\ ${ }^{a}$ Division of Pathogenic Biochemistry, Institute of Natural medicine, ${ }^{b}$ International Exchange Group, \\ Research Promotion Division, and 'Division of Medicinal Pharmacology, Institute of Natural \\ medicine, University of Toyama, 2630 Sugitani, Toyama 930-0194, Japan
}

(Received December 11, 2008)

\begin{abstract}
The Core University Program provides a framework for international cooperative research in specifically designated fields and topics, centering around a core university in Japan and its counterpart university in other countries. In this program, individual scientists in the affiliated countries carry out cooperative research projects with sharply focused topics and explicitly delineated goals under leadership of the core universities. The Core University Program which we introduce here has been renewed since 2001 under the support of both the Japan Society for the Promotion of Science (JSPS) and the National Research Council of Thailand (NRCT). Our program aims to conduct cooperative researches particularly focusing on Natural Medicine in the field of Pharmaceutical Sciences. Institute of Natural Medicine at University of Toyama (Japan), Faculty of Pharmaceutical Sciences at Chulalongkorn University (Thailand), and Chulabhorn Research Institute (Thailand) have been taking part in this JSPS-NRCT Core University Program as core universities. The Program is also supported by the 20 institution members in both countries. This program is running the five research subject under a key word of natural medicine which are related to i) age-related diseases, ii) allergy and cancer, iii) hepatitis and infectious diseases, iv) structure, synthesis, and bioactivity of natural medicines, and v) molecular biology of Thai medicinal plant components and database assembling of Thai medicinal plants. The program also encourages university members to strengthen related research activities, to share advanced academic and scientific knowledge on natural medicines.
\end{abstract}

Key words_— natural medicine; cooperative research; core university exchange program

\section{1. はじめに}

拠点大学方式による学術交流事業とは, 日本学術 振興会（JSPS）によるアジア諸国との連携強化を 目的とした国際交流事業のうちの 1 つで，特定の研 究分野及び研究課題を対象とした国際共同研究を,

2 国間（若しくは多国間）の研究者の交流により組 織的に実施しているものである.

拠点大学交流事業は 1977 年の文部省の学術審議 会建議に基づき翌 1978 年度からスタートし, 当初 は東南アジア諸国（タイ，インドネシア，マレーシ ア，フィリピン，ベトナム）との間で実施され，そ

$a$ 富山大学和漢医薬学総合研究所病態生化学分野, $b$ 同 大学研究振興部国際交流グループ, $c$ 同大学和漢医薬学 総合研究所複合薬物薬理学分野 (干930-0194 富山市杉 谷 2630)

*e-mail: byosei@inm.u-toyama.ac.jp

本総説は, 日本薬学会第 128 年会シンポジウム S39 で 発表したものを中心に記述したものである.
の後，中国，韓国，インドが加わつた。2007 年度 (平成 19 年度) 現在の拠点大学交流事業実施状況は 2 国間交流によるものが 20 件，多国間交流による ものが 2 件となっており，2010 年度 (平成 22 年度) の末ですべての課題が終了する予定である.

2 国間交流では, 両国に共同研究の中核となる大 学（拠点大学）に加えて，その拠点大学を中心とし 共同研究に参加する大学 (協力大学) 及び協力大学 以外に所属して共同研究に参加する個々の研究者 （協力研究者）からなるグループがそれぞれ形成さ れ，両拠点大学間の協議に基づき毎年作成される研 究計画により共同研究及び研究者交流を実施してい る.

2. 夕イ拠点大学交流事業「薬学分野 · 天然薬物」 の組織

われわれの受託した事業（以下本事業と呼ぶ）は タイとの 2 国間交流によるもので，2001 年度から 
2010 年度の 10 年間に渡つて「薬学分野・天然薬物」 を交流分野・研究テーマとして次のような組織で実 施している。

日本側対応機関であるJSPS とタイの対応機関で ある夕イ学術研究会議（NRCT）の合意の下，日本 側グループ・9大学と, タイ側グループ・12 の大学 及び研究所に加え, タイ側の了解を得てベトナム・ 2 研究機関により組織されている。なお，ベトナム は天然薬物資源の豊富な国であり，天然薬物に焦点 を絞って共同研究を継続・発展させる目的で，特別 に参加して頂いている．参加機関名は次の通りであ る.

\section{日本側}

拠点大学(1)：富山大学和漢医薬学総合研究所

協力大学(8): 千葉大学大学院薬学研究院, 東京大学 大学院薬学系研究科, 名古屋大学大学 院生命農学研究科, 広島大学大学院医 歯薬学総合研究科, 九州大学大学院薬 学研究院, 岐阜薬科大学, 北里大学北 里生命科学研究所, 明治薬科大学

\section{タイ側}

拠点大学(2): チュラロンコン大学薬学部, チュラポ ン研究所

協力大学(12)：チェンマイ大学薬学部, コンケン大学 薬学部, マハサラカム大学薬学健康科 学部, マヒドン大学薬学部, ナレスワ ン大学薬学部, プリンスオブソンクラ 大学薬学部, シラパコーン大学薬学 部,スリナカリンウィロー大学薬学 部, ウボンラチャタニ大学薬学部, カ セサート大学理学部, ベトナム国立伝 統医学病院, ベトナム国立薬物研究所

\section{3. 本事業の背景}

本事業の前身に，日本側に東京大学薬学部の三川 潮教授 (当時), タイ側にチュラロンコン大学薬学 部 Pavich Tongroach 薬学部長（当時）を両コーデ イネーターとして 1990 年度（平成 2 年）から 1999 年度（平成 11 年度）の 10 年間実施された夕イとの 拠点大学交流事業「薬学」がある。富山大学（旧 富山医科薬科大学）はその事業に日本側協力大学と して参加していたが，事業終了に当たりタイ側の交 流継続への強い要望等を受けて，その交流実績を引 き継ぎ「天然薬物」をテーマに実施組織を再構築し
た新たなプログラムとして申請し，2001 年度（平 成 13 年度）に採択された。そのため本事業で 2 回 目の開催となるジョイントセミナー 2006 は，タイ 側の要望などから以前の事業から通算して 7 回目と なること示す意味で第 7 回となっている.

歴代の拠点大学コーディネーターは，日本側が富 山医科薬科大学和漢薬研究所の渡邊裕司元所長 (2001-2003 年度), 服部征雄前所長（2004-2005 年 度）を経て，2006 年度から富山大学和漢医薬学総 合研究所長の済木育夫が務めている。タイ側は拠点 機関が 2 つあり，チュラロンコン大学では Sunibhond Pummangura 元薬学部長 (2001 年), Boonyong Tantisira 前薬学部長（2002-2005 年）を経て，2006 年より Pornpen Pramyothin 薬学部長（2006 年から 現在)に, チュラポン研究所では Somsak Ruchirawat 副所長（2001 年から現在）にご尽力頂いている.

\section{4. 研究目標之 5 つの課題}

タイ，ベトナムは熱帯から亜熱帯に位置し，薬用 資源の世界的に豊富な地域であるが，近年の乱開発 により貴重な薬用資源が失われつつある。このよう な状況下で，日本とタイ・ベトナム側が協力して， 東南アジアの薬用資源の保全と人類の健康・福祉へ の有効利用を目指し，社会的問題となっている老年 性認知症，生活習慣病，新規ウイルス性感染症など の難治性疾患の予防や治療に有用な薬物のシーズ （種）を探索し，新しい薬物の開発を行うことを本 事業の研究目標としている.

この目標達成のために，本事業は天然薬物の探索 及び老人性疾患，アレルギー性疾患，がん，エイ ズ，肝炎，マラリアなどの各種疾病をターゲットと した課題 1-3, 天然薬物成分の化学的及び分子生物 学的研究の課題 4, さらに夕イ産薬用植物のデー夕 ベースの作成の課題 5 に分かれて共同研究を実施し ている。事業開始当初は 6 つの課題でスタートした が，当初の課題 6「マラリアに有効な天然薬物の研 究」を 2005 年度からは課題 3 に含めて実施してい る. 研究目標及び各課題を次に示す.

研究目標：東南アジアの薬用資源を活用して老年 性認知症，生活習慣病，新規ウイルス 性感染症などの難治性疾患の予防や治 療に有用な薬物のシーズ（種）を探索 し，新しい薬物の開発を行なう

研究課題 $\mathrm{R}-1$ : 老人性疾患の予防と治療に有用 
な天然薬物の研究

R-2 : アレルギー性疾患及びがんの予 防や浸潤，転移を抑制する天然 薬物の研究

R-3：肝炎（肝障害を含む）及び数種 の感染症に有効な天然薬物の研 究

R-4：天然物の構造，合成，活性発現 の分子機構の研究

R-5：タイ産薬用植物成分の生合成に 関する分子生物学とバイオテク ノロジー研究，及びタイ産薬用 植物のデータベースの確立

\section{5. 本事業実施の流れ}

本事業の実施方針は日本側拠点大学と 8 協力大学 代表者からなる連絡協議会で決定され，研究課題代 表者が派遣研究者の推薦を含めた研究課題別の年間 実施計画を作成する。同時にタイ側コーディネー ターからも派遣研究者が推薦（ノミネートリストの 送付）される。それらを受けて日本側コーディネー ターが翌年度の実施計画書を作成し，JSPS 事務局 に提出する.

新年度に入ると，JSPS は前年度交流実績を基に 委託費（研究交流経費及び委託手数料）を算出し, 日本側拠点大学（富山大学）との間で事業委託契約 を締結する．日本側コーディネーターはその金額の 範囲で双方の派遣研究者を決定・通知し，本事業を 開始する。

年度末には, 日本側研究課題代表者からの実施報 告を受けて日本側コーディネーターが実施報告書を 作成し，JSPS 事務局に提出する.

\section{6. 委託費の使途について}

JSPS と富山大学との業務委託契約に基づき配分 される本事業の業務委託費には，交流の実施に直接 必要な「研究交流経費」と，その $10 \%$ 以内の「委 託手数料」がある。

日本・タイ双方の経費分担は JSPS と NRCT と の覚書により決められている。例えばジョイントセ ミナーを実施する場合は，参加研究者の海外渡航費 は支出できるが，タイで開催した場合には，セミ ナ一開催費用や参加研究者の国内旅費は夕イ側の負 担とされている．また，共同研究の場合，タイ側の 研究費は夕イ側で負担することになっている。この
ように交流実施にはタイ側の財政的協力も不可欠で あるが，申請方式がマッチングファンド方式を取っ ていないため, タイ側の資金調達面に問題が生じて いる.

「研究交流経費」の支出内訳は，「国内旅費及び外 国旅費の合計は研究交流経費総額の $50 \%$ 以上でな ければならない」と事業取り扱い手引きに定められ ているが，本事業における旅費はその $80 \%$ 以上を 占めている，翌年度以降の配分額が相手国との交流 実績（交流総人日数）により算定されるため，予算 を研究費にまわすとその分だけ交流実績が減り，結 果として翌年度の予算が減らされることになるた め，必然的にそのほとんどを旅費として支出せざる を得ない点に事業展開の困難さがある.

\section{7. 交流実績}

本事業の交流実績（総交流人数・総人日数）のう ちの交流人数の年度別比較を Table 1 に示した.

2003 年と 2006 年度は，それぞれジョイントセミ ナーの開催地側の受け入れ人数が多い傾向がみられ るものの，一般的にタイからの受入れ人数が多くな っている.

一方，人日数の比較では，タイから日本の受入人 日数が日本からタイへの派遣人日数よりも圧倒的に 多くなっている。この要因は日本側からの派遣滞在 期間がおおむね 1 週間程度であるのに対して，タイ 側からの受入滞在期間が 1-3 カ月であることによる ものある.

タイ側からの受入研究者には 2 つのパターンがあ る。すなわち，若手研究者の育成のため交流経験を 積むことを目的とする一次・短期型と，同じ研究者 を繰り返し派遣して共同研究実績を挙げることを目 的とする反復・長期型である。一次・短期型の割合 が比較的多い，その主な理由は，少しでも多くの研 究者に交流を体験させることをタイ側が重視してい

Table 1. Comparison of No. of Scientists Exchanged in FY2001-2006

\begin{tabular}{lrrrrrr}
\hline \hline 年度 & 2001 & 2002 & 2003 & 2004 & 2005 & 2006 \\
派遣総数（人) & 18 & 27 & 46 & 25 & 21 & 19 \\
受入総数（人) & 27 & 31 & 20 & 31 & 25 & 48 \\
派遣総数（人日） & 114 & 182 & 299 & 167 & 140 & 114 \\
受入総数（人日） & 1193 & 1383 & 986 & 1459 & 1271 & 767 \\
予算 (万円) & 2330 & 2986 & 2736 & 2686 & 2620 & 1834 \\
\hline
\end{tabular}


るためである。

\section{8. ジョイントセミナーの開催について}

本事業では JSPS と NRCT とのジョイントセミ ナーを 2-3 年毎に開催しており，2006 年 12月 1-4 日には富山で 2 回目の (前身から通算して第 7 回目) ジョイントセミナーを開催した。研究発表者数は夕 个 30 名（口頭発表 13 名を含む），日本 27 名（同 11 名), ベトナム 1 名（同 1 名）, 参加者総数は 104 名である。開催経費は拠点大学交流経費に加えて富 山大学の学長裁量経費及び重点配分経費を充当し, タイ側から高い評価を得ることができた。なお，第 1 回は“Recent Advances in Natural Medicine Research”, をテーマとして 2003 年 12 月 2-3 日バンコ クで開催しており，第 3 回は“Innovative Research in Natural Products for Sustainable Development", をテーマにバンコクで開催予定であり，これまでに 得られた交流成果の公開と，共同研究における双方 の update を図っている.

\section{9. 今後の検討課題}

2005 年度に実施された中間評価結果を受けて, 研究課題内の研究者間や課題を越えた研究者間の相 互交流を一層促進するため，以下に示す実施方針の 基に具体的な実施計画を立案し，より実質的かつ効 果的な交流を目指している.

実施方針

- 参加研究者が相互の研究内容をより理解し易 い組織に見直す

- 参加研究者から研究内容・交流実績に関する 幅広い情報を収集し提供する

- タイ側からの受入研究者を帰国後もフォロー アップし，研究者の二ーズに応える

- 次世代の指導者的立場となる両拠点若手研究 者を共同研究の実施により支援する

具体的な実施計画

- 日本側研究者の所属課題を再編成・課題代表 者の役割強化（2006 年度より実施）

- 日本側研究者の個人プロファイル作成（2007 年度実施済夕）とその公開（2008 年度更新・ 公開予定）

- 夕イ側研究者の個人プロファイル作成（2007 年度より着手)

- 両拠点交互にジョイントセミナーを開催 （2003 及び 2006 年度実施済み，2008 年度夕
イで実施予定）

- 夕イ側受入研究者を対象にフォローアップセ ミナーを企画・タイで開催（2007 年度より 実施)

\section{0. 共同研究成果の一部紹介}

現行の共同研究の中から, 研究課題 2 「アレル ギー性疾患及びがんの予防や浸潤・転移を抑制する 天然薬物の研究」の研究成果の一部について紹介す る.

インドを原産地とするウコン (Curcuma longa L.）はショウガ科に属し，中国や日本では漢方薬 成分として利用されている。また，インドをはじめ 多くの国々で香辛料としても重用されており，力 レーの黄色成分の主体である。 その黄色色素である curcumin は，非ステロイド系のポリフェノールで あり，抗酸化作用，抗菌作用，抗炎症作用，健胃作 用，抗血栓作用，利尿作用などの多くの薬理作用が 報告されている。 また，抗腫瘍効果に加えて，最近 抗転移効果が報告されており，その作用メカ二ズム の解明や臨床利用の可能性が注目されている.

われわれは独自に確立したがん細胞の同所性移植 による自然転移モデルを用いて， curcumin ががん 転移を強く抑制することを示した。すなわち，マウ ス Lewis lung carcinoma（LLC）細胞をマトリゲル に懸濁し，開胸せずに注射器にて肺実質に移植する と，移植部位での単結節状の腫瘍増殖に加えて縦隔 リンパ節への転移が認められる。この転移モデルに おいて curcumin (100, $200 \mathrm{mg} / \mathrm{kg}$, p.o. $)$ の評価を 行つたところ，興味深いことに移植部位の原発腫瘍 の増殖には影響を及ぼさなかつたが，縦隔リンパ節 への転移を用量依存的に抑制した。また，肝がん細 胞株 CBO140C12 の腫瘍塊の肝臓への同所性移植に よる肝内転移モデルにおいても，LLC の場合と同 様に原発腫瘍の増殖には影響を及ぼさないが，肝内 転移を強く抑制することを明らかにした。このよう に，顕著な腫瘍退縮効果を示さない用量においても， curcumin は強い抗転移効果を示すことを見い出し た。したがって，この curcumin の転移抑制効果は 単なる腫瘍に対する直接的な増殖抑制効果に基づく ものではなく，転移成立に係わるステップを特異的 に阻害している可能性が考えられた。実際，マウス 皮膚がん B16F-10 メラノーマを用いた実験的肺転 移モデルにおいても， curcumin が肺への転移を阻 
害する作用を示し，その結果，寿命延長作用を示す ことも報告した。

そこで，LLC や CBO140C12 細胞の in vitroにお ける培養系において，細胞傷害性を示さない濃度に おいて転移に関連する重要な機能に対する curcumin の効果を検討した。その結果，LLC 肺がん細 胞の in vitro 浸潤能を顕著に抑制した。また，転写 因子 AP-1 活性を抑制するとともに，その転写因子 AP-1 により発現調節される urokinase-type plasminogen activator（u-PA）やその受容体（u-PAR） の mRNA 発現をも抑制した。一方, CBO140C12 肝細胞がんの場合でも, in vitro 浸潤能の抑制に加
えて，がん細胞から由来する MMP-9 の産生を阻害 する作用を有していることを見い出した。また， fibronectin やlaminin などの細胞外基質成分に対す るがん細胞の接着能も阻害し，それにはインテグリ ン受容体の活性化に伴う actin stress fiber の形成阻 害が係わっていることを示唆する結果を得ている.

以上のように, curcumin による転移抑制効果に は，転移過程における様々な機能を，細胞傷害性を 示さない濃度において阻害する機序に基づく可能性 が示唆された。今後，がんの薬物治療において，特 異的な転移抑制薬としての役割に期待がかかる. 